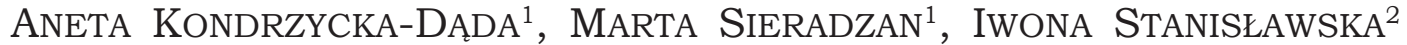

${ }^{1}$ Warszawska Uczelnia Medyczna im. T. Koźluka

Bobrowiecka 9, 00-728 Warszawa

${ }^{2}$ Wyższa Szkoła Rehabilitacji

Kasprzaka 49, 01-234 Warszawa

E-mali: akondrzycka@irpro.pl

martasieradzan@onet.pl

iwonabiol@wp.pl

\section{BEZPIECZEŃSTWO I HIGIENA W CZASIE PANDEMII COVID-19 W MIEJSCACH UŻYTECZNOŚCI PUBLICZNEJ}

\section{WIRUS SARS-CoV-2}

SARS-CoV-2 jest czynnikiem etiologicznym COVID-19 (ang. coronavirus disease 2019).

Chorobę wywoływana przez nowy typ koronawirusa zdiagnozowano po raz pierwszy w grudniu 2019 r. W Chinach, w miejscowości Wuhan odnotowano znaczny wzrost zachorowań na zapalenie płuc o nieznanej etiologii. Po szeregu badań wyizolowano wirusa, który jest blisko spokrewniony $z$ wirusem SARS (zespół ciężkiej ostrej niewydolności oddechowej) (Vellas i współaut. 2020). SARS-CoV-2 wykazuje wysoki stopień zakażalności i szybko okazał się dużym problemem. Mimo środków podjętych przez władze Chin epidemia koronawirusa rozprzestrzeniała się wywołujacc pandemię.

Pierwszy potwierdzony przez WHO przypadek zachorowania na kontynencie europejskim odnotowano 25 stycznia 2020 r. we Francji. Od tego momentu pandemia koronawirusa zaczęła obejmować kolejne państwa, dotarła także do Polski. 4 marca 2020 r. ówczesny minister zdrowia, Łukasz Szumowski, ogłosił obecność pierwszej osoby chorej na COVID-19, nazwanej „pacjentem zero”.

\section{SPOSOBY ROZPRZESTRZENIANIA WIRUSA SARS-CoV-2}

Osoba zarażona podczas oddychania czy kaszlu rozprzestrzenia drobne kropel- ki wydzieliny zawierajacej czastki infekcyjne wirusa. Zdrowa osoba, pozostajaca $\mathrm{w}$ bliskim kontakcie $\mathrm{z}$ chora (w odległości mniejszej niż 2 metry), może wdychać kropelki tej wydzieliny, co spowoduje jej zarażenie. Do zakażenia może też dochodzić bez bezpośredniego kontaktu $\mathrm{z}$ chorym. Kropelki wydalane przez chora osobę osadzaja się na powierzchni przedmiotów i moga pozostawać w formie infekcyjnej nawet do kilkunastu godzin. Aby zdrowa osoba uległa zakażeniu, musi mieć kontakt $z$ przedmiotami, na których osadziły się wirusy. Może się to wydarzyć poprzez przeniesie wirusa na rękach do ust, nosa czy oczu (KAUR i współautm 2021, МоHAMADIAN i współaut. 2021).

$\mathrm{W}$ analizie rozprzestrzeniania się SARS-CoV-2 ważna rolę odgrywa wskaźnik $R_{0}$ (współczynnik reprodukcji wirusa), który pokazuje, ile osób może zakazić jedna osoba chora na COVID-19. Przyjmuje się, że gdy spada on poniżej 1, mamy do czynienia $z$ opadająca falą, zaś jeśli jest wyższy od 1, fala pandemii zaczyna się wznosić.

$Z$ najnowszych danych wynika, że epidemia koronawirusa w Polsce znajduje się na fali wznoszacej. Świadczy o tym wskaźnik $R_{0}$, który 5 października 2021 r. w skali kraju wyniósł 1,22. Najwyższy wskaźnik $R_{0}$ w tym okresie był na Podlasiu 1,35 i na Mazowszu 1,31. 


\section{SPOSOBY ZAPOBIEGANIA ROZPRZESTRZENIANIU SIE WIRUSA SARS-CoV-2}

Stale rosnąca liczba przypadków zarażenia SARS-CoV-2 spowodowała konieczność wprowadzenia kilku zasad, które maja na celu ograniczenie lub eliminację transmisji wirusa. Obejmuja one przede wszystkim izolację osób chorych, dezynfekcje środowiska i stosowanie środków ochrony osobistej. Rzad Polski wprowadził zasadę DDM (dezynfekcja, dystans, maseczki). Ponadto zalecił jak najczestsze mycie rak woda $z$ mydłem i dezynfekcję płynami na bazie alkoholu (>60\%), należy także zachowywać odległość przynajmniej 1,5 metra od innych osób. W przestrzeniach zamkniętych i w środkach komunikacji miejskiej powinno się zasłaniać usta i nos maseczka.

Zgodnie $z$ wytycznymi WHO dotyczacymi zapobiegania rozprzestrzeniania COVID-19, należy chronić osoby najbardziej narażone na działanie wirusa (szczególnie osoby leczone onkologicznie, po przeszczepach oraz osoby starsze) przez szczepienia. WHO zaleca także wprowadzenie nieograniczonego dostępu do wykonywania testów wykrywajacych COVID-19, a nawet podanie trzeciej dawki szczepionki osobom $z$ upośledzona odpornością.

\section{PRZEBIEG OBOSTRZEŃ WPROWADZONYCH NA CZAS PANUJAZCEJ PANDEMII COVID-19}

Stan epidemiologiczny zwiąany w wystapieniem i niekontrolowanym rozprzestrzenianiem się nowej, groźnej choroby zakaźnej spowodował, że niezbędne stało się wprowadzenie szeregu obostrzeń dostosowywanych okresowo do aktualnej sytuacji.

Gdy 4 marca 2020 r. został w Polsce potwierdzony pierwszy przypadek zachorowania na COVID-19, Ministerstwo Zdrowia zaleciło wzmożona czujność, potrzebę alarmowania w przypadku podejrzenia zarażenia SARS-CoV-2, powszechne stosowanie systemu DDM.

16 kwietnia 2020 r. wprowadzono obowiazek zakrywania ust i nosa w miejscach publicznych (nakaz, a nie zalecenie). Ograniczono liczbę osób mogacych przebywać jednocześnie w zamkniętych pomieszczeniach. W placówkach handlowych i usługowych wprowadzono obowiazek zapewnienia klientom środków dezynfekcyjnych do rak. Powszechnie zaczęto stosować rękawiczki jednorazowe.

Liczba osób, u których stwierdzono zakażenie SARS-CoV-2, stale wzrastała. Nakazano izolację osób chorych, ale kwaran- tanna objęte zostały również osoby, które miały kontakt $z$ chorym, nawet mimo braku objawów. Okres obowiązkowej kwarantanny zmieniał się wraz ze wzrastajaca świadomościa na temat przebiegu choroby. Poczatkowo okres ten wynosił $14 \mathrm{dni}$, potem zmniejszono go do 10, ostateczna decyzja należała do Państwowej Inspekcji Sanitarnej.

8 sierpnia wprowadzono zasadę regionalnego zaostrzania/łagodzenia obostrzeń. Polska została, w zależności od liczby zachorowań, podzielona na trzy strefy: zielona, żółta i czerwona. Obszary, które znajdowały się w strefie zielonej mogły funkcjonować bez obostrzeń. W strefie żółtej wprowadzono szereg ograniczeń: w transporcie publicznym można było zajmować $50 \%$ miejsc siedzacych lub 30\% wszystkich miejsc; imprezy masowe (także rodzinne uroczystości) mogły skupiać jednorazowo maksymalnie 20 osób; w uroczystościach religijnych mogła uczestniczyć 1 osoba na $4 \mathrm{~m}^{2}$, a w zgromadzeniach publicznych 25 osób; lokale gastronomiczne mogły działać między godz. 6.00 a 21.00 przy 50\% obłożeniu; szkoły wyższe i ponadpodstawowe działy w systemie hybrydowym; zawieszona została działalność basenów i siłowni; wydarzenia sportowe mogły się odbywać, ale bez udziału publiczności, natomiast wydarzenia kulturalne przy $25 \%$ zajętych miejsc.

8 października cała Polska znalazła się w strefie żółtej. Mimo wprowadzenia ograniczeń pandemia nadal postępowała.

23 października nastąpiła konieczność wprowadzenia w całym kraju strefy czerwonej. Oprócz dotychczasowych obostrzeń w tej strefie wprowadzono: ograniczenie liczby osób w placówkach handlowych: w zależności od powierzchni handlowej było to 5 osób na kasę (powierzchnia do $100 \mathrm{~m}^{2}$ ) oraz 1 osoba na $15 \mathrm{~m}^{2}$ (powierzchnia powyżej 100 $\left.\mathrm{m}^{2}\right)$; absolutny zakaz imprez okolicznościowych; w uroczystościach religijnych mogła uczestniczyć 1 osoba na $7 \mathrm{~m}^{2}$, a w zgromadzeniach publicznych 10 osób; w szkołach wyższych i ponadpodstawowych nauka odbywała się wyłacznie w trybie zdalnym.

28 grudnia 2020 r. wprowadzono kwarantannę narodowa, popularnie nazywana lock-downem. Wiazało się to $z$ maksymalnymi obostrzeniami, zamknięte zostały hotele, galerie handlowe, punkty gastronomiczne mogły serwować jedzenie wyłacznie na wynos. Zaapelowano o ograniczenie w przemieszczaniu się i, o ile to możliwe, o pozostanie w domach.

Pod koniec stycznia i w lutym nastapiło stopniowe luzowanie obostrzeń. Od 27 lutego 2021 r. nakazano noszenie w przestrzeni publicznej maseczki i wskazano je jako jedyny skuteczny sposób zapobiegania roznosze- 
nia cząsteczek wirusowych. Przyłbice, szaliki, apaszki i tym podobne zostały wyłączone z dopuszczonych form osłonięcia ust i nosa.

W marcu 2021 r. odnotowano znaczny wzrost zachorowań na COVID-19, w zwiąku $z$ czym od 27 marca ponownie zaostrzono ograniczenia, które trwały do 26 kwietnia, kiedy zdecydowano, że spadek liczby zachorować jest trwały.

Od 1 maja 2021 r. otwarto salony fryzjerskie i kosmetyczne w całej Polsce, 15 maja zniesiono obowiazek noszenia masek ochronnych na świeżym powietrzu, ale utrzymano obowiązek ich zakładania w pomieszczeniach zamkniętych, a od 29 maja powrócono do nauki stacjonarnej na wszystkich poziomach nauczania.

W okresie letnim liczba wykrywanych przypadków COVID-19 znacznie zmalała. Kolejna, IV fala rozpoczęła się jesienia, a jej przebieg zależeć będzie w głównej mierze od poziomu zaszczepienia populacji Polski. Niestety jest on w dalszym ciagu niezadawalajacy. Dotychczasowe zalecenia epidemiologiczne zostały utrzymane. Dodatkowe wytyczne dotyczą głównie jednostek oświatowych. W zwiazku $z$ nadejściem IV fali MEiN przygotowało zalecenia, których celem jest bezpieczna organizacja zajęć w jej trakcie. Ministerstwo Edukacji i Nauki, wspólnie z Rządowa Agencja Rezerw Strategicznych, przekazało do szkół i przedszkoli stacje dezynfekujace z funkcja mierzenia temperatury, rękawiczki, maseczki, płyny dezynfekujące i termometry. Większość placówek edukacyjnych uruchomiła także punkty szczepień dla chętnych uczniów.

Od początku września 2021 r. trzecia dawkę szczepionki przeciw SARS-CoV-2 moga przyjmować osoby leczone onkologicznie, po przeszczepach, $z$ niedoborem odporności lub zakażone HIV, a od 24 września także osoby, które ukończyły 50 lat. Od 2 listopada dawke uzupełniajaca będa mogły przyjąć osoby, które ukończyły 12 lat i otrzymały pełny schemat szczepienia preparatami dopuszczonymi w UE.

\section{AKTUALNE ZASADY BEZPIECZEŃSTWA W INNYCH MIEJSCACH PUBLICZNYCH}

Dzięki wprowadzonym obostrzeniom oraz wdrożeniu systemu powszechnych szczepień udało się nieco zwolnić pandemię. Nie znaczy to jednak, że możemy całkowicie zrezygnować ze wszystkich ograniczeń. W dalszym ciagu obowiąuja przepisy dotyczace utrzymania minimum 1,5 metra odległości pomiędzy pieszymi, $z$ wyłączeniem rodziców z małoletnimi dziećmi, osób wspólnie mieszkających oraz osób $z$ niepełnosprawnościami i ich opiekunów. Zasłanianie ust i nosa za pomoca maseczki w pomieszczeniach zamkniętych dotyczy całego kraju. Oznacza to, że powinno się nosić maseczkę w środkach transportu miejskiego: autobusach, tramwajach i pociagach, jak również $w$ galeriach handlowych, sklepach, dyskontach, bankach, urzędach, na poczcie, w kinach, teatrach, operach, kościołach, przychodniach i szpitalach. W miejscu pracy, jeśli w pomieszczeniu przebywa więcej niż jedna osoba (chyba, że w uzasadnionych przypadkach pracodawca ustali inaczej) lub jeśli pracownik ma bezpośredni kontakt $z$ klientami, również powinny być stosowane maseczki. Liczba miejsc, gdzie ustawowo wprowadzono ten obowiazek, jest dosyć obszerna. Gdzie zatem wymóg ten nas nie obowiazuje? Bez dodatkowych środków ochronnych możemy przebywać na świeżym powietrzu, w parkach, lesie, ogrodzie, na drogach, placach, parkingach, cmentarzach, w podróży, jeśli poruszamy się prywatnym środkiem lokomocji, w restauracjach, barach i innych miejscach bezpośrednio w trakcie spożywania posiłku. $Z$ obowiazku zasłaniania ust sa też zwolnione osoby, które posiadają zwolnienie lekarza ze względu na różnego rodzaju zaburzenia zdrowia.

W zależności od ryzyka epidemiologicznego w różnych miejscach pożytku publicznego wprowadzono nieco odmienne formy obostrzeń.

Muzea i galerie sztuki otwarto w reżimie sanitarnym, określając limit osób - 1 os./10 $\mathrm{m}^{2}$. W kinach zalecono zredukowanie liczby oglądajacych do $75 \%$ maksymalnego obłożenia. Podobnie jest w teatrach, operach, filharmoniach, a także domach kultury - max. $75 \%$, ale przy zapewnieniu maksymalnej gęstości 1 os./10 $\mathrm{m}^{2}$. Koncerty i widowiska cyrkowe realizowane w pomieszczeniach opieraja się na analogicznych wytycznych, natomiast jeśli odbywaja się na świeżym powietrzu nie moga skupiać więcej niż 250 osób, przy czym do limitu nie sa wliczane osoby zaszczepione przeciwko COVID-19. Dodatkowo, mimo iż przedstawienie odbywa się w plenerze, w takiej sytuacji zachodzi potrzeba zakrywania maseczka nosa i ust. Parki rozrywki działające na świeżym powietrzu musza ograniczyć liczbę odwiedzajacych do $75 \%$ maksymalnego obłożenia.

Biblioteki powinny realizować limity, podobnie jak muzea czy teatry, czyli nie więcej niż 1 os./10 $\mathrm{m}^{2}$, do limitów nie są włączani pracownicy. Jeśli w ramach działalności organizowane sa spotkania, to nie powinny one skupiać więcej niż 15 osób, należy również pamiętać o zachowaniu między nimi prawidłowej odległości - min. 1,5 m.

Zgromadzenia na świeżym powietrzu moga skupiać nie więcej niż 150 osób, po- 
między którymi powinno się zachować odległość min. 1,5 m. Dodatkowo, jeśli na tym samym terenie organizowane jest więcej niż jedno zgromadzenie, odległość między nimi musi wynosić przynajmniej $100 \mathrm{~m}$.

Uroczystości religijne na świeżym powietrzu (rekomendowane) podlegaja analogicznym rozporządzeniom, natomiast jeśli odbywaja się $\mathrm{w}$ miejscach kultu powinny stosować normę 75\% maksymalnego obłożenia.

Spotkania, wesela, komunie, konsolacje, przyjęcia $\mathrm{i}$ inne uroczystości rodzinne czy firmowe maja analogiczne ograniczenia. Dodatkowo obowiazuja wytyczne dotyczace rozstawienia stolików: może być zajęty co drugi albo odległość pomiędzy nimi musi wynosić co najmniej 1,5 m. Alternatywnie można również zastosować przegrodę pomiędzy stolikami, a jej wysokość musi wynosić min. 1 $\mathrm{m}$ od powierzchni stolika.

Limit 150 osób dotyczy także imprez rozrywkowych, takich jak: dyskoteki i kluby nocne.

Konferencje, kongresy, ale także wystawy $\mathrm{i}$ targi musza być organizowane $\mathrm{w}$ reżimie sanitarnym, $z$ zachowaniem limitu 1 osoby na $\mathrm{m}^{2}$. Zasady te obowiazuja także $\mathrm{w}$ sklepach i centrach handlowych.

Lokale gastronomiczne, a także restauracje hotelowe moga mieć $75 \%$ obłożenia i co drugi stolik zajęty lub zapewnione przegrody pomiędzy stolikami. Limity nie dotyczą osób zaszczepionych i zorganizowanych grup dzieci poniżej 12 r.ż.

W siłowniach i klubach fitness obowiazuja limity 1 osoby na $10 \mathrm{~m}^{2}$, natomiast baseny i wodne parki moga działać przy $75 \%$ obłożeniu. Podczas wydarzeń sportowych można udostępnić publiczności tylko 50\% miejsc, a całkowita liczba osób w obiekcie nie może przekroczyć 500 osób. Limity nie dotyczą osób zaszczepionych (https://www. gov.pl/web/koronawirus/aktualne-zasady-i-ograniczenia).

\section{PODSUMOWANIE}

Choroby zakaźne nie sa niczym nowym w życiu człowieka, jednak pojawienie się nowego, nieznanego wirusa mocno wstrzasnęło światem. Największy problem stanowiła nieznajomość nowego patogenu, zarówno w kontekście jego oddziaływania na ludzki organizm, jak i metod przeciwdziałania zakażeniu. Właśnie ta niewiedza powodowała często niespójne decyzje prewencyjne. Wraz $z$ rozwojem świadomości na temat patogenezy SARS-CoV-2 ewoluowały metody pozwalające efektywnie zabezpieczyć się przed zachorowaniem na COVID-19.

Bezsprzecznie najwydajniejsza metoda sa szczepionki przeciwwirusowe. Równoległe stosowanie w praktyce zasady DDM (dezynfekcja, dystans, maseczki) jest zalecane i wydajne.

Szereg zaleceń kierowanych do określonych miejsc użyteczności publicznej ma na celu zapewnienie bezpieczeństwa $\mathrm{w}$ ich użytkowaniu.

Organizacje i stowarzyszenia obejmujace sektory poszczególnych branż opracowały i upowszechniły poradniki, przewodniki, opracowania omawiające najważniejsze punkty dotyczace zachowania bezpieczeństwa świadczonych usług. Pracodawcy rozumieja, że zachowanie bezpieczeństwa zależy zarówno od klientów, jak i osób świadczących usługi, a naszym wspólnym, nadrzędnym celem jest zmniejszenie ryzyka transmisji wirusa SARS$-\mathrm{CoV}-2$.

Powrót do tzw. normalności jest potrzebny nie tylko ze względów ekonomicznych, ale także, a może przede wszystkim, ze względów psychologicznych. Nawiazywanie czy podtrzymywanie więzi społecznych jest jedna $z$ podstawowych potrzeb człowieka. Izolacja, która początkowo była niezbędna, w długiej perspektywie czasowej może się okazać niezwykle szkodliwa. Tym bardziej zasadne jest przestrzeganie ustanowionych sektorowo obostrzeń.

\section{Streszczenie}

Stan epidemiologiczny związany w wystapieniem i niekontrolowanym rozprzestrzenianiem się nowej, groźnej choroby zakaźnej COVID-19 spowodował, że niezbędne stało się wprowadzenie szeregu obostrzeń dostosowywanych okresowo do aktualnej sytuacji. Jednak dzięki wprowadzonym zasadom bezpieczeństwa oraz wdrożeniu systemu powszechnych szczepień udało się nieco spowolnić pandemię. Gruntowne poznanie objawów, przebiegu i leczenia choroby COVID-19 pozwoli na opracowanie skutecznych środków zapobiegawczych rozprzestrzeniania się tej choroby.

\section{LITERATURA}

KaUR A., Bhalla V., Salahuddin M., Rahman S. O., PotToO F. H., 2021. COVID -19 infection: Epidemiology, virology, clinical features, diagnosis and pharmacological treatment. Curr. Pharm. Des. 27, 3551-3565.

Mohamadian M., CHITI H., SHOGHLi A., Biglari S., Parsamanesh N., EsmaeilzadeH A., 2021. COVID-19: Virology, biology and novel laboratory diagnosis. J. Gene. Med. 23, doi: $10.1002 / \mathrm{jgm} .3303$.

Vellas C., Delobel P., De Souto Barreto P., IZOPET J., 2020. COVID-19, virology and geroscience: A Perspective. J. Nutr. Health Aging 24, 685-691.

\section{OBOWIAZZUJACE AKTY PRAWNE}

Rozporzadzenie Rady Ministrów $z$ dnia 6 maja 2021 r. w sprawie ustanowienia określonych ograniczeń, nakazów i zakazów w związku z 
wystapieniem stanu epidemii, https://dziennikustaw.gov.pl/D2021000086101.pdf.

Rozporzadzenie Rady Ministrów $z$ dnia 10 maja 2021 r. zmieniajace rozporządzenie w sprawie ustanowienia określonych ograniczeń, nakazów i zakazów w zwiazku $z$ wystapieniem stanu epidemii, http://isap.sejm.gov.pl/isap. nsf/download.xsp/WDU20210000879/O/ D20210879.pdf.

Rozporządzenie Rady Ministrów $z$ dnia 14 maja 2021 r. zmieniajace rozporządzenie w sprawie ustanowienia określonych ograniczeń, nakazów i zakazów w zwiazku $z$ wystapieniem stanu epidemii, https://dziennikustaw.gov.pl/ D2021000090501.pdf.

Rozporządzenie Rady Ministrów z dnia 25 maja 2021 r. zmieniające rozporządzenie w sprawie ustanowienia określonych ograniczeń, nakazów i zakazów w zwiazku $z$ wystapieniem stanu epidemii, https://dziennikustaw.gov.pl/ D2021000095701.pdf.

Rozporządzenie Rady Ministrów z dnia 4 czerwca 2021 r. zmieniajace rozporzadzenie w sprawie ustanowienia określonych ograniczeń, nakazów i zakazów w związku $z$ wystapieniem stanu epidemii, https://dziennikustaw.gov.pl/ D2021000101301.pdf.

Rozporzadzenie Rady Ministrów z dnia 11 czerwca 2021 r. zmieniajace rozporządzenie w sprawie ustanowienia określonych ograniczeń, nakazów i zakazów w zwiąku $z$ wystapieniem stanu epidemii, https://isap.sejm.gov.pl/isap. nsf/download.xsp/WDU20210001054/O/ D20211054.pdf.
Rozporzadzenie Rady Ministrów z dnia 22 czerwca 2021 r. zmieniajace rozporządzenie w sprawie ustanowienia określonych ograniczeń, nakazów i zakazów w zwiazku $z$ wystapieniem stanu epidemii, https://dziennikustaw. gov.pl/D2021000111601.pdf.

Rozporzadzenie Rady Ministrów z dnia 23 czerwca 2021 r. zmieniające rozporządzenie w sprawie ustanowienia określonych ograniczeń, nakazów i zakazów w związku $z$ wystapieniem stanu epidemii, https://dziennikustaw. gov.pl/D2021000112501.pdf.

Rozporzadzenie Rady Ministrów z dnia 25 czerwca 2021 r. zmieniajace rozporzadzenie w sprawie ustanowienia określonych ograniczeń, nakazów i zakazów w związku $z$ wystapieniem stanu epidemii, https://dziennikustaw. gov.pl/D2021000114501.pdf.

Rozporzadzenie Rady Ministrów z dnia 9 lipca 2021 r. zmieniajace rozporzadzenie w sprawie ustanowienia określonych ograniczeń, nakazów i zakazów w zwiazku $z$ wystapieniem stanu epidemii, https://dziennikustaw.gov.pl/ D2021000126201.pdf.

Rozporządzenie Rady Ministrów z dnia 27 sierpnia 2021 r. zmieniajace rozporządzenie w sprawie ustanowienia określonych ograniczeń, nakazów i zakazów w związku $z$ wystapieniem stanu epidemii, https://dziennikustaw. gov.pl/D2021000158301.pdf.

KOSMOS Vol. 70, 3, 445-449, 2021

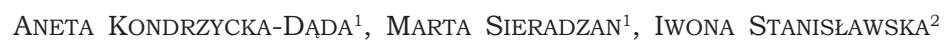

${ }^{1}$ Tadeusz Koźluk Medical University of Warsaw, 9 Bobrowiecka Str., 00-728 Warszawa; ${ }^{2}$ Warsaw College of Rehabilitation, 49 Kasprzaka Str., 01-234 Warszawa, E-mali: E-mali: akondrzycka@irpro.pl, martasieradzan@onet.pl, iwonabiol@wp.pl

\section{SAFETY AND SANITATION DURING THE COVID-19 PANDEMIC IN PUBLIC AREA}

\section{Summary}

The epidemiological situation related to the occurrence and uncontrolled spread of the new dangerous infectious disease - COVID-19 made it necessary to introduce a number of restrictions periodically adjusted to the current situation. Thanks to the introduced safety rules and the implementation of a system of universal vaccination, it was possible to slightly slow down the pandemic. A thorough understanding of the symptoms, course and treatment of COVID-19 will allow the development of effective measures to prevent the spread of this disease. 